Tinjauan Pustaka

\title{
Patofisiologi, Tanda dan Gejala Sindrom Dapson serta Tatalaksananya
}

\author{
William \\ Staf Pengajar Bagian Farmakologi, Fakultas Kedokteran Universitas Kristen Krida Wacana \\ Alamat Korespondensi: williamvesca@gmail.com
}

\begin{abstract}
Abstrak
Sindrom Dapson adalah sindrom yang jarang terjadi tetapi memiliki angka mortalitas yang tinggi. Sindrom ini merupakan reaksi hipersensitivitas tipe lambat yang timbul dengan variasi waktu antara 48 jam - 6 bulan setelah penggunaan Dapson dan tidak bersifat dose-dependant. Sindrom ini memiliki tampilan klinis berupa demam, erupsi kulit, limfadenopati, dan kelainan hati atau organ lainnya. Patofisiologi sindrom ini belum jelas tetapi diperkirakan disebabkan oleh metabolit Dapson yaitu hidroksilamin yang merupakan hapten dan memperantarai sel $\mathrm{T}$ untuk mengenali antigen tersebut. Tingkat keparahan sindrom ini tergantung dari keparahan organ yang terkena sehingga dapat bersifat asimptomatik sampai mengancam jiwa. Diagnosis sindrom ini ditegakkan jika terdapat minimal 2 gejala dari gejala di atas dan belum ada pemeriksaan penunjang yang spesifik. Sindrom ini merupakan bagian dari DRESS (drug reaction with eosinophilia and systemic syndrome) tetapi pada sindrom Dapson tidak selalu ada eosinofilia. Penanganan sindrom ini dilakukan dengan cara menghentikan Dapson yang merupakan obat penyebab secepatnya dan glukokortikoid serta terapi suportif. Oleh karena sindrom ini memiliki angka mortalitas yang tinggi maka perlu dikenali lebih dini dan ditangani dengan tepat.
\end{abstract}

Kata kunci : Sindrom Dapson, hipersensitivitas, glukokortikoid, mortalitas, diagnosis.

\section{Pathophysiology, Signs and Symptoms of Dapson Syndrome and Its Management}

\begin{abstract}
Dapsone syndrome is a rare syndrome with high mortality rate. It is a delayed type hypersensitivity reaction that occurs in a variation of time between 48 hours to 6 months after consuming Dapsone and it is not dose-dependent. The symptoms are fever, skin eruption, lymphadenopathy, and liver or another organ dysfunction. Its pathophysiology is not clear yet but it is assumed to be caused by Dapsone metabolite (hydroxylamine) which is a hapten that is able to facilitate $T$ cells to recognize the antigen. The severity of this syndrome is from asymptomatic to life threatening. The diagnosis is confirmed when at the minimum two of those symptoms above occurred. There is no specific laboratory of radiologic examinations to establish the diagnosis. This syndrome is part of DRESS (drug reaction with eosinophilia and systemic syndrome) but Dapsone syndrome is not always has eosinophilia. The treatment is to stop the drug immediately, give glucocorticoid, and other supportive therapy. Because of its high mortality rate, it is essential that the symptoms be recognized earlier thus the treatment can be manage properly.
\end{abstract}

Keywords: Dapsone syndrome, hypersensitivity, glucocorticoid, mortality, diagnosis. 


\section{Pendahuluan}

Sindrom dapson yang dikenal juga sebagai "five weeks dermatitis" merupakan reaksi hipersensitivitas akibat obat yang timbul secara tiba-tiba setelah 5-6 minggu penggunaan dapson. Sindrom ini dimulai setelah pajanan yang lama dengan variasi waktu sekitar 48 jam-6 bulan sehingga berbeda dengan reaksi hipersensitivitas akibat obat yang lain. Tampilan klinis dari reaksi hipersensitivitas akibat dapson dapat berupa demam, kemerahan pada kulit, limfadenopati generalisata, hepatitis, dan hepatosplenomegali. ${ }^{1}$

Kejadian reaksi hipersensitivitas akibat dapson pertama kali ditemukan oleh Lowe pada awal tahun 1950 di Nigeria kemudian pada tahun 1951 diberi nama sindrom dapson oleh Allday dan Barnes. Kejadian sindrom ini telah dilaporkan pada berbagai negara di dunia meliputi Asia, Eropa, Amerika Utara, Afrika, Australia dan didominasi oleh negara Asia terutama India dan Cina. ${ }^{1,2}$ Dari systematic review yang dilakukan oleh Lorenz $\mathrm{M}$, dkk (2011) menyatakan bahwa angka kejadian sindrom ini sekitar $1,4 \%$ dengan rentang usia 5-83 tahun dan mempunyai fatality rate sebesar 9,9\%. ${ }^{2}$ Menurut studi terakhir yang dilakukan di Cina oleh Tian WW, dkk (2012) insiden sindrom dapson sekitar $1 \%$ dengan angka mortalitas sekitar $11,1 \%$ sedangkan di Indonesia telah dilaporkan 1 kasus sindrom Dapson pada tahun 2014 di RS Sitanala, Tangerang. ${ }^{3,4}$

Sindrom dapson jarang terjadi tetapi dapat meningkatkan mortalitas dan morbiditas jika tidak dikenali dan ditangani secara cepat sehingga penulis merasa perlu untuk menulis artikel ini yang akan membahas mengenai gejala, tanda klinis, dan pemeriksaan penunjang serta pengobatan yang diperlukan untuk mengatasi sindrom dapson ini.

\section{Farmakokinetik dan Farmakodinamik Dapson}

Dapson diserap lambat dalam saluran cerna tetapi hampir sempurna. Kadar puncak dapson dapat tercapai dalam waktu 1-3 jam dengan kadar $10-15 \mathrm{mcg} / \mathrm{mL}$ setelah pemberian dosis yang dianjurkan. Kadar puncak ini cepat turun tetapi masih dijumpai dalam jumlah yang cukup setelah 8 jam. Waktu paruh eliminasi Dapson sekitar 20-30 jam dengan rata-rata 28 jam. Pada dosis kecil berulang, sejumlah kecil kadar obat masih ditemukan dalam darah hingga 35 hari setelah penghentian penggunaan obat. Dapson memiliki ikatan protein plasma sebesar $50-70 \%$ dan mengalami proses metabolisme berupa asetilasi oleh NAT-2 dan oksidasi oleh enzim CYP2E1 dan CYP2C menjadi dapson hidroksilamin. Dapson hidroksilamin ini akan masuk ke dalam sel darah merah dan membentuk methemoglobin. Obat ini tersebar luas di seluruh jaringan tubuh dan cairan tubuh yang cenderung bertahan di jaringan kulit, otot, ginjal, dan hati selama 3 minggu. Dapson diekskresikan melalui urin sekitar 70-80\% dalam bentuk asam yang labil yaitu asam mono N-glutamat dan mono-N-sulfamat., ${ }^{4,5}$

Dapson memiliki mekanisme kerja sebagai penghambat enzim dihydropteroate synthase pada jalur pembentukan asam folat dan memiliki efek sebagai antiinflamasi dengan menghambat kerusakan jaringan yang disebabkan oleh neutrofil. Dapson merupakan obat yang memiliki spektrum pengobatan yang luas yaitu sebagai antibakterial, antiprotozoal, dan antijamur sehingga biasa digunakan untuk mengobati penyakit infeksi yang disebabkan oleh Mycobacterium leprae, Plasmodium falciparum, dan Pneumocystic jiroveci. Oleh karena dapson juga memiliki efek antiinflamasi maka dapson sering digunakan untuk beberapa penyakit inflamasi kulit dan jaringan lunak seperti pemfigoid, dermatitis herpetiformis, linear IgA bullous disease, kondritis kambuhan, dan ulkus yang disebabkan oleh brown recluse spider. ${ }^{5}$

Efek samping yang umum terjadi akibat penggunaan dapson adalah hemolisis terutama pada pasien dengan defisiensi enzim G6PD (Glucose 6-phosphate dehydrogenase) dan methemoglobinemia. Methemoglobinemia ini umumnya terjadi jika dapson diberikan dengan dosis 200-300 mg/hari dan methemoglobinemia berat terjadi akibat kelainan genetik dengan defisiensi enzim $\mathrm{NADH}$ dependent methemoglobin reductase. Efek samping yang lain dapat berupa sakit kepala, gelisah, insomnia, pandangan kabur, parestesia, neuropati perifer reversibel, drug fever, gatal, psikosis, dan berbagai kelainan kulit. Penggunaan dapson pada kehamilan harus hati-hati karena termasuk dalam kategori C sehingga harus dipertimbangkan antara keuntungan dan kerugiannya jika ingin digunakan pada wanita hamil. ${ }^{5,6}$ 


\section{Patofisiologi Sindrom Dapson}

Sindrom dapson ini merupakan suatu reaksi hipersensitivitas tipe lambat yang jarang ditemukan. Tes stimulasi limfosit yang positif dan dominasi sel $\mathrm{T}$ sitotoksik yang teraktivasi di permukaan dermis pasien sindrom dapson menunjukkan bahwa sindrom ini merupakan reaksi alergi dan bukan reaksi idiosinkrasi. ${ }^{3,7,8}$

Patofisiologi sindrom ini masih belum jelas tetapi diperkirakan disebabkan oleh metabolit dapson yang merupakan hasil metabolisme dari dua jalur yaitu $\mathrm{N}$-asetilasi dan $\mathrm{N}$ hidroksilasi. Jalur $\mathrm{N}$-asetilasi tidak berhubungan dengan kejadian efek samping dapson tetapi jalur N-hidroksilasi akan menghasilkan hidroksilamin yang merupakan senyawa toksik dan berperan pada kejadian anemia hemolitik dan sindrom dapson. ${ }^{3}$ Produksi metabolit toksik tersebut disebabkan oleh ketidakseimbangan proses metabolisme di hati yaitu penurunan proses asetilasi dan peningkatan proses hidroksilasi yang cepat. ${ }^{8}$ Metabolit toksik tersebut adalah hapten yang dapat memodifikasi beberapa senyawa imunologis seperti MHC (Major Histocompatibility Complex) pada permukaan sel imun kemudian akan memperantarai sel $\mathrm{T}$ untuk mengenali antigen tersebut. ${ }^{3}$

Faktor - faktor lainnya yang berperan menyebabkan hemolisis ikut berperan untuk terjadinya sindrom dapson seperti modified graft versus host disease type of reaction yang berhubungan dengan aktivasi sel $\mathrm{T}$ dan defisiensi enzim glutation sintetase untuk proses detoksifikasi metabolit toksik. ${ }^{7,8}$

Beberapa penelitian pada populasi Cina menunjukkan adanya hubungan antara sindrom dapson dengan keberadaan
HLAB*13;01 dan keberadaan satu lokus dalam MHC (Major Histocompatibility Complex) sebagai faktor risiko dan prediktor sindrom dapson, tetapi hal ini membutuhkan penelitian lebih lanjut. ${ }^{9}$

Proses penuaan dan penyakit hati yang kronis dapat menjadi salah satu faktor proteksi kejadian sindrom dapson karena penurunan aktivitas enzim metabolisme sehingga produk toksik sedikit dihasilkan. ${ }^{7}$

\section{Gejala Klinik Sindrom Dapson}

Istilah sindrom dapson pertama kali dikenal pada tahun 1951 yang sebelumnya oleh Lowe \& Smith disebut sebagai "glandula fever" pada tahun 1949. Sindrom ini memiliki trias klasik gejala klinik berupa demam, erupsi kulit, dan keterlibatan organ tubuh. ${ }^{1,10}$ Leta, dkk mengklasifikasikan sindrom dapson menjadi dua bentuk yaitu bentuk lengkap (complete) dan bentuk tidak lengkap (incomplete). Bentuk lengkap ditandai dengan adanya rash, demam, limfadenopati, hepatomegali dan adanya bukti klinis atau hasil laboratorium gangguan fungsi hati, sedangkan bentuk yang tidak lengkap jika tidak terdapat minimal satu gejala tersebut. ${ }^{3}$

Gejala klinik lainnya yang dapat ditemukan pada sindrom dapson dapat dilihat pada tabel 1 di bawah ini. Variasi dari gejala klinik tersebut (tabel 1) akan ditemukan pada pasien dengan berbagai kombinasi gejala yang berbeda-beda untuk setiap pasien dengan sindrom dapson., ${ }^{2,8}$ Beberapa laporan kasus menunjukkan bahwa sindrom ini mulai terjadi setelah 2-10 hari atau paling lambat 6 bulan atau bahkan lebih lama lagi setelah pemberian dapson. ${ }^{1,10}$ 
Tabel 1. Manifestasi Klinik Sindrom Dapson ${ }^{1,7,10}$

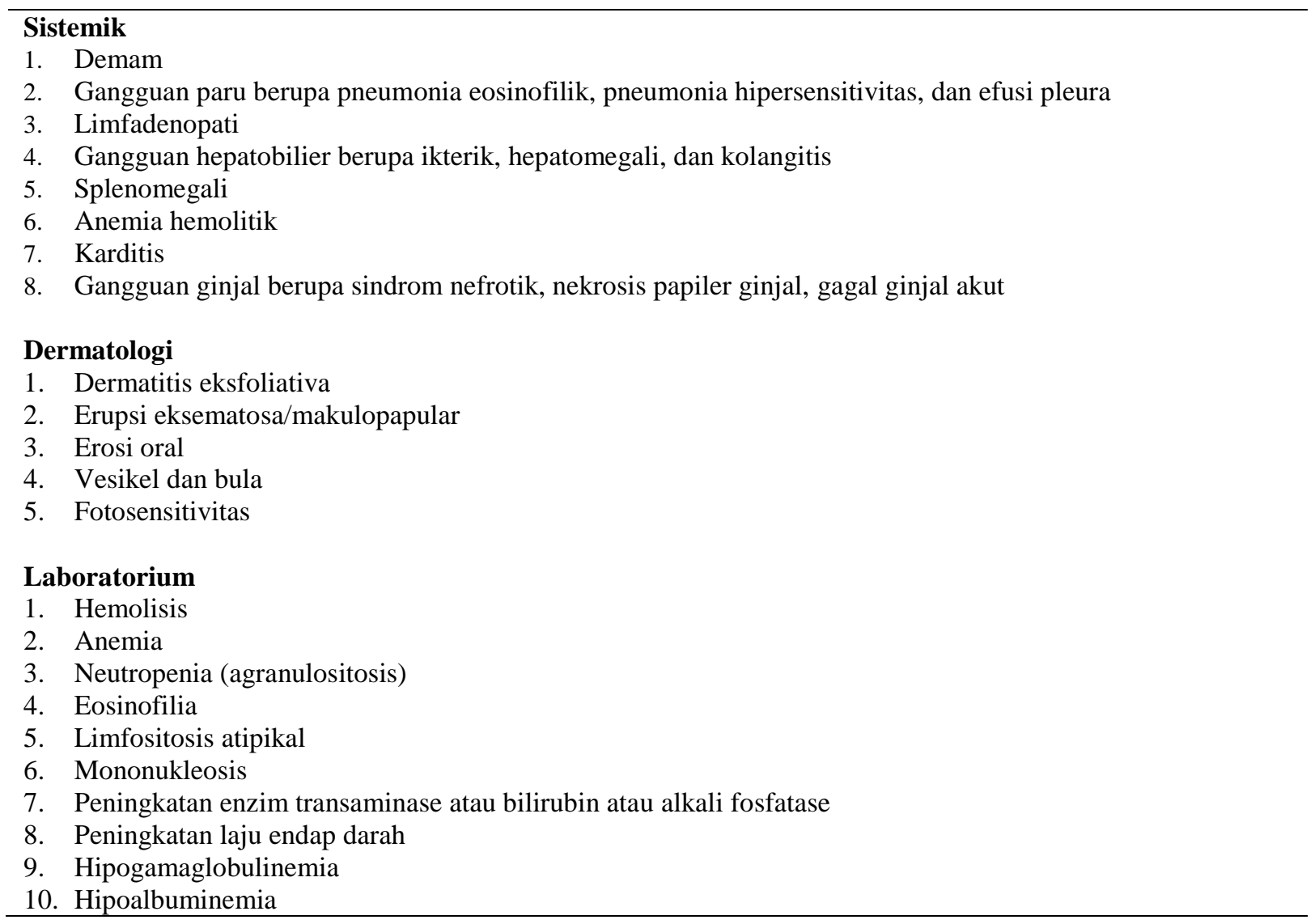

Tingkat keparahan sindrom ini di daerah kulit tidak berkaitan dengan tingkat keparahan organ dalam tubuh yang mungkin bersifat asimptomatik hingga mengancam jiwa. Lesi di daerah kulit biasanya akan mengalami penyembuhan dalam 2 minggu setelah penghentian dapson tetapi beberapa pasien dapat mengalami kelainan kulit yang lebih berat seperti Steven Johnson syndrome atau toxic epidermal necrolysis (TEN) sehingga akan memperpanjang lamanya penyakit dan bahkan kematian dengan berbagai komplikasi. Terutama pada beberapa kasus yang berat, keadaan malnutrisi, kehilangan protein plasma, dan infeksi sekunder dapat memperparah kondisi penyakit sehingga pasien dengan keadaan ini memerlukan pengawasan yang lebih ketat. ${ }^{4,10}$

\section{Pemeriksaan Penunjang}

Pemeriksaan penunjang yang dapat dilakukan adalah pemeriksaan laboratorium seperti pemeriksan darah lengkap yang biasanya disertai dengan hitung jenis leukosit, laju endap darah, analisa urin, dan analisa gas darah. Pemeriksaan lainnya yang dapat dilakukan adalah pemeriksaan rontgen dan pada beberapa kasus tertentu dapat dilakukan pemeriksaan CT-scan, Ultrasound hati, dan atau biopsi kulit. Biopsi kulit mungkin tidak spesifik tetapi dapat membantu menyingkirkan diagnosis vaskulitis atau keganasan darah. Selain itu, penting juga dilakukan pemeriksaan kadar TSH (Thyroid Stimulating Hormone) setelah $3-4$ bulan terdiagnosis dengan sindrom dapson karena dapat terjadi hipotiroidisme yang disebabkan oleh adanya autoantibodi (antibodi antimikrosomal) dan tidak dapat dilakukannya detoksifikasi metabolit aktif yang diproduksi oleh tiroid peroksidase sehingga akan menimbulkan reaksi hipersensitivitas. ${ }^{10}$

\section{Diagnosis Sindrom Dapson}

Sindrom dapson tidak bersifat dosedependant sehingga sindrom ini dapat terjadi pada dosis yang bervariasi. ${ }^{9}$ Diagnosis sindrom dapson ditegakkan jika terjadi reaksi hipersensitivitas setelah penggunaan dapson selama $2-8$ minggu yang umumnya diikuti 
oleh dua dari gejala berikut yaitu demam, erupsi kulit, limfadenopati, dan gangguan fungsi hati baik secara klinis seperti hepatomegali dan ikterik maupun penilaian hasil pemeriksaan di laboratorium seperti tes fungsi hati yang abnormal. ${ }^{7}$

Diagnosis banding sindrom dapson adalah sindrom DRESS (drug reaction with eosinophilia and systemic syndrome), vaskulitis (Churg Strauss Syndrome), sindrom hipereosinofilia, nekrolisis epidermal toksik, sindrom Steven Johnson's, Still's disease, kelainan darah seperti leukemia dan limfoma, sindrom paraneoplastik, dan kelainan jaringan penghubung tertentu. Sindrom dapson merupakan bagian dari DRESS, pada DRESS terjadi eosinofilia sedangkan sindrom dapson tidak selalu terjadi eosinofilia. ${ }^{10}$

\section{Penanganan Sindrom Dapson}

Sindrom dapson yang tidak ditangani dengan cepat bersifat fatal dan dapat menyebabkan kematian yang disebabkan oleh kegagalan fungsi organ. Penanganan sindrom dapson tidak boleh dilakukan dengan rechallenge karena metabolit aktif dapson yang sangat berbahaya. ${ }^{8}$ Penanganan sindrom dapson dapat dilihat pada tabel 2 dibawah ini. Penanganan utama sindrom ini adalah penghentian penggunaan dapson secepatnya disertai dengan penggunaan glukokortikoid oral atau parenteral seperti prednison, prednisolon, atau metilprednisolon. Penurunan dosis bertahap glukokortikoid dilakukan setelah penggunaan $>1$ bulan, disebabkan oleh dapson masih ditemukan dalam tubuh manusia sampai 35 hari karena berkaitan dengan ikatan proteinnya. ${ }^{10}$

Jika pasien tidak dapat diberikan glukokortikoid disebabkan oleh adanya kontraindikasi seperti glaukoma, osteoporosis berat, hiperglikemia, dan psikosis berat maka dapat diberikan imunosupresan seperti metotreksat, azatioprin, sikosporin, atau hidroksiklorokuin, meskipun belum adanya penelitian yang baik mengenai penggunaan imunosupresan tersebut tetapi mungkin dapat menguntungkan pasien dengan kondisi kontraindikasi glukokortikoid. ${ }^{10}$

Tabel 2. Penanganan Sindrom Dapson ${ }^{10}$

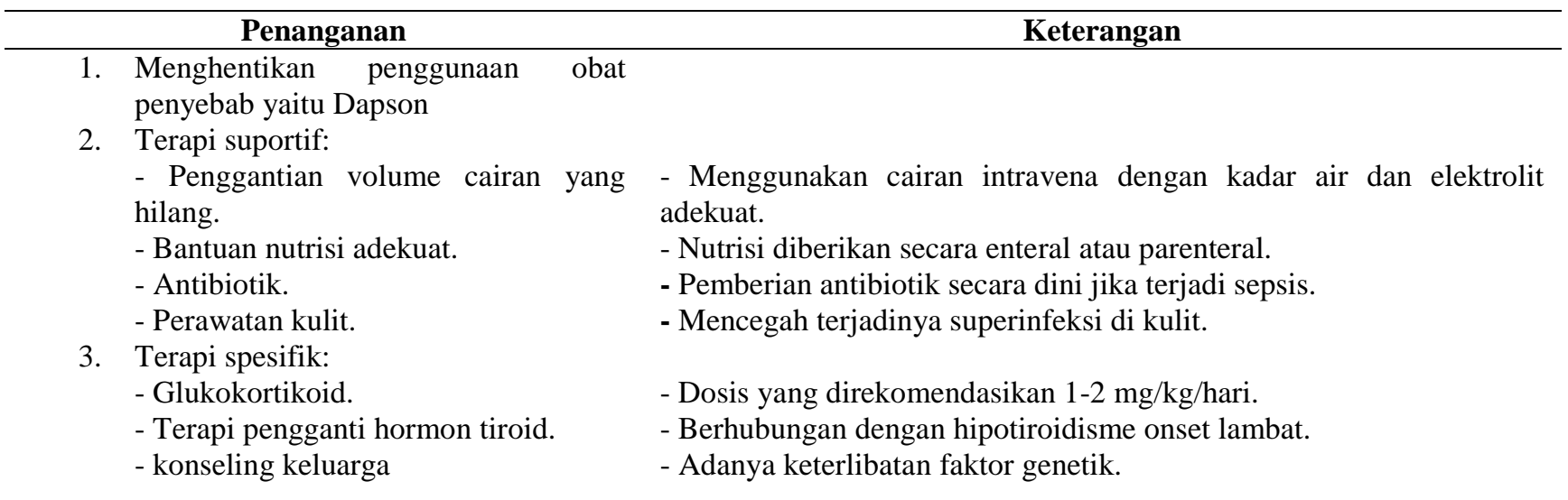

\section{Penutup}

Sindrom dapson merupakan reaksi hipersensitivitas tipe lambat yang jarang yang mengenai berbagai usia. Sindrom ini disebabkan oleh penggunaan dapson dengan manifestasi klinis utama adalah demam, erupsi kulit, limfadenopati, dan kelainan hati. Sindrom ini dapat mengenai organ tubuh lainnya dengan manifestasi klinis sesuai dengan organ tubuh yang dikenainya. Oleh karena sindrom ini mengenai berbagai organ tubuh maka dapat mengakibatkan kegagalan fungsi organ yang bersifat fatal bahkan kematian sehingga diperlukan pengenalan secara dini sindrom ini supaya dapat dilakukan penanganan secara cepat dan tepat. Penanganan sindrom dapson terutama adalah menghentikan penggunaan dapson secepatnya dan pemberian glukokortikoid dengan dosis sekitar 1-2 $\mathrm{mg} / \mathrm{kg} / \mathrm{hari}$ sesuai beratnya penyakit serta terapi suportif lainnya. 


\section{Daftar Pustaka}

1. Thappa DM, Sethuraman G. Dapson (sulfone) syndrome (CME). Indian Journal of Dermatology, Venereology, And Leprosy. 2000;66:117-20.

2. Lorenz M, Wozel G, Schmitt J. Hypersensitivity reactions to dapson: a systematic review. Acta Derm Venereol 2012;92:194-9.

3. Tian WW, Shen J, Zhou M, Yan L, Zhang G. Dapson hypersensitivity syndrome among leprosy patients in china. Lepr Rev. 2012;83:370-7.

4. Kusumastanto VA, Esti PK. Laporan kasus sindrom dapson pada pasien morbus hansen. CDK-225;2015; 42 (2): 123-5.

5. Goodman and Gilman's. Chemotherapy of tuberculosis, Mycobacterium avium complex disease, and leprosy. Manual of pharmacology and therapeutic handbook. McGraw-Hill company $2^{\text {nd }}$ ed chapter 56. 2014; 953-4.

6. Actavis UK Ltd. Dapsone tablets BP 50 mg. emc. 2016. Diunduh dari https://www.medicines.org.uk/emc/medic ine/23938. Diunduh tgl 10 September 2017.

7. Alungal J, Abdulla MC, Kunnummal NK, Sivadasan A. Dapson-induced hypersensitivity syndrome, hemolytic anemia, and severe agranulocytosis. International Journal of Nutrition, Pharmacology, Neurological Diseases. 2015;5:113-6.

8. Bucaretchi F, Vicente DC, Pereira RM, Tresoldi AT. Case report dapsone hypersensitivity syndrome in an adolescent during treatment of leprosy. Rev. Inst. Med. Trop. S. Paulo. 2004;46(6):331-4

9. Gavilanes MC, Palacio AL, Chelini PR, Da Costa Nery JA, Rego JG. Dapsone Hypersensitivity Syndrome in Lepromatous Leprosy Patient - A case report. Lepr Rev. 2015;86:186-90.

10. Kosseifi GS, Guha B, Nassour DN, Chi DS, Krishnaswamy G. The dapsone hypersensitivity syndrome revisited: A potensially fatal multisystem disorder with prominent hepatopulmonary manifestations. Journal of Occupational Medicine and Toxicology. 2006;1(9):1-9. 